\title{
Analysis of the Impact of Covid-19 on Different Sectors in Turkey During Early Periods of the Pandemic
}

\author{
Zeyneb Hafsa ORHAN iD a Nurullah TIRMAN ${ }^{\text {iD }}$ b \\ a Istanbul Sabahattin Zaim University, Department of Islamic Economics and Finance, Istanbul, Turkey. hafsa.orhan@izu.edu.tr \\ b Istanbul Sabahattin Zaim University, Department of International Finance and Participation Banking, Istanbul, Turkey. \\ tirman.nurullah@std.izu.edu.tr
}

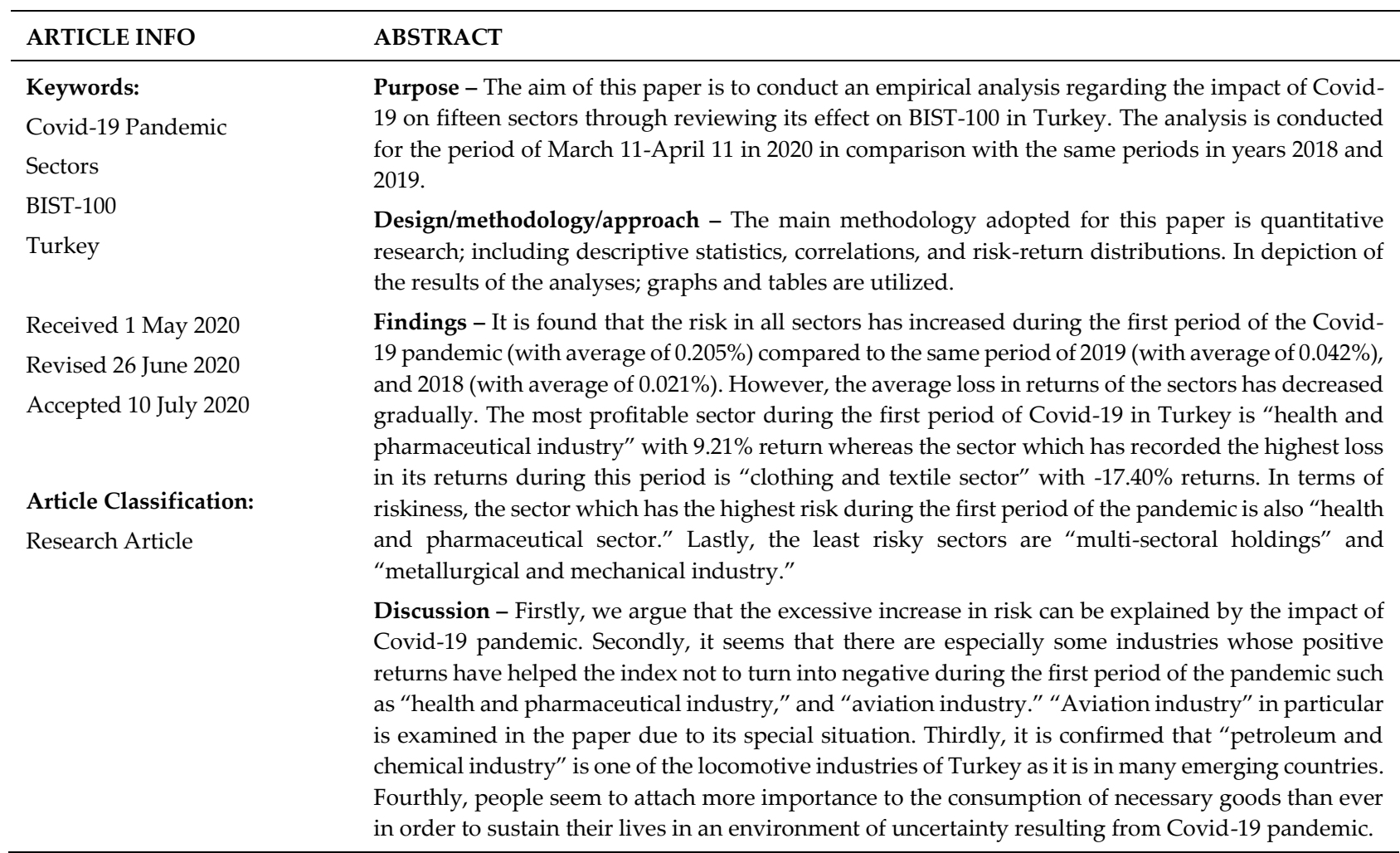

\section{INTRODUCTION}

Many epidemic diseases have been experienced in the world throughout history. Nowadays, humanity struggles with Covid-19 which is a mutated version of coronavirus. Covid-19 firstly appeared in China in December 2019, then spread around the world, and now it has become a pandemic. Over the past four months, negative effects of Covid-19 pandemic reduced in China whereas rest of the world such as Iran, Italy, Spain, Germany, England, and the USA are now experiencing the worst of it. As of April 11, total confirmed cases are more than 1.6 million and total deaths are about a hundred thousand worldwide (WHO, 2020). Negative effects of the pandemic have been accelerated since last December. Therefore, people needed stay at their homes to avoid and prevent spreading of the pandemic. Hence, the situation has affected social and cultural activities besides health all over the world.

In a strongly interdependent world, the effects of pandemic have become apparent especially in economic field. Global supply chain, production, trade and financial markets have been disrupted (Açıgöz and Günay, 2020; McKibbin and Fernando, 2020; Zeren and Hizarc1, 2020). Accordingly, IMF (International Monetary Fund) announced its growth forecast for world GDP (Gross Domestic Product) as negative for the first quarter of 2020 by lowering annual world growth forecast from 3.3\% to $-3.0 \%$ (IMF, 2020). Correspondingly, financial markets have also been affected negatively by this pandemic due to strong correlation among investment, 
production and output. Moreover, uncertainty of human behavior during the virus outbreak is affecting asset prices (Ramelli \& Wagner, 2020) and market equilibrium (McKibbin and Fernando, 2020) directly or indirectly. For this reason, global financial markets reacted to these changes, and thus, global stock markets declined.

The first case of Covid-19 appeared in Turkey on March 11. Over the last one-month period, negative effects of the pandemic have been accelerated. As of April 11, total confirmed cases are more than 52 thousand and total deaths are more than 1.1 thousand (T.R. Ministry of Health, 2020). Economic conditions have been affected also Turkey and its economy as the world. Therefore, the Turkish government took several measures under the terms of economic recovery program in order to prevent that the economic conditions arising from the pandemic become worse. Nevertheless, real sectors of Turkey have been affected negatively due to detrimental local and global economic circumstances. Hence, this situation has been reflected in BIST (Borsa Istanbul) 100 Index as seen on Figure1.

BIST 100 Index Prices $\quad$ BIST 100 Index Returns

$700.000,00$

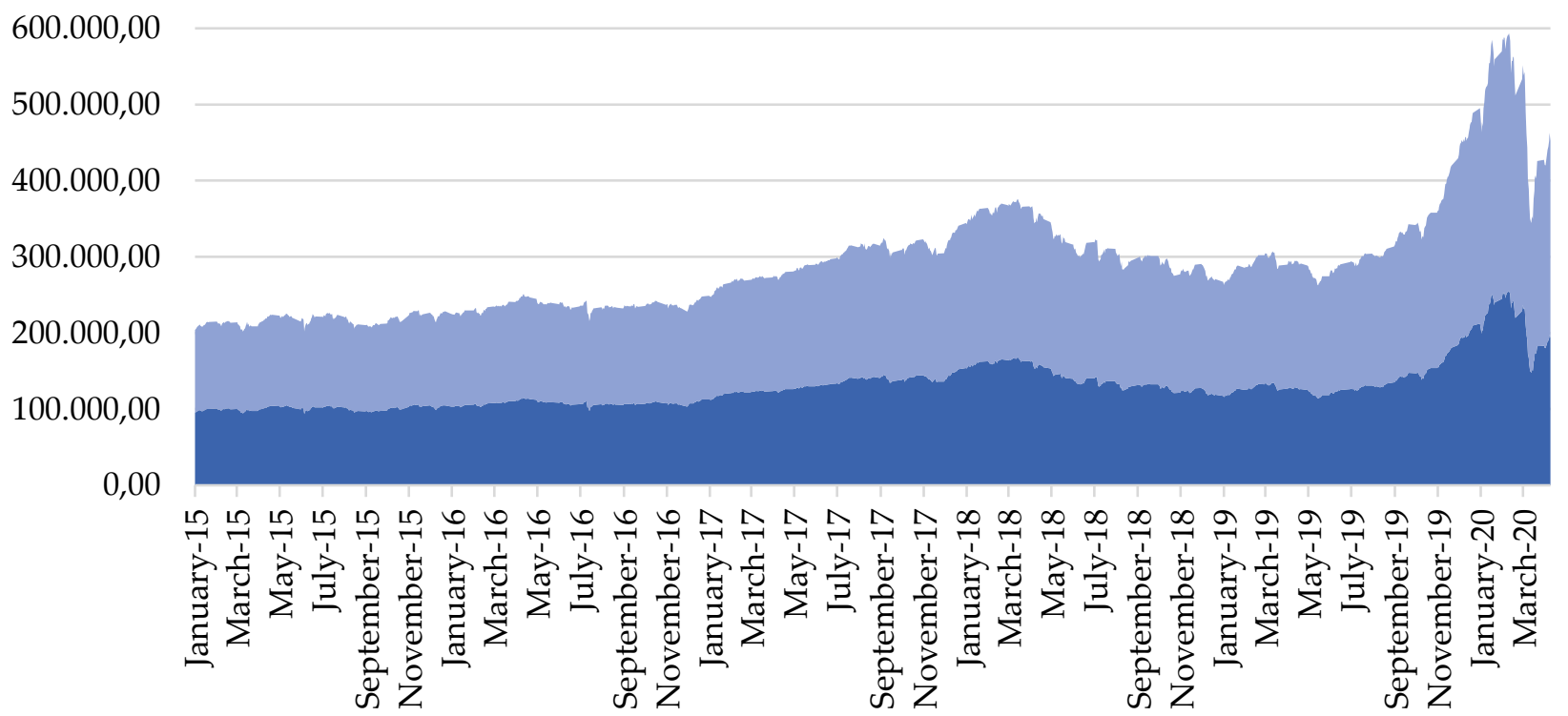

Figure 1. BIST 100 Index Prices and Returns in Turkey, January 2015-April 20201

Source: CBRT, EVDS Data Central, BIST 100 All Shares Index, According to Closing Price, Business Days Data, 2015-2020.

Figure1 shows the simultaneous daily price and return movements of the BIST 100 Index from 2 January 2015 to 10 April 2020. BIST is the stock market of Turkey. In the given period, BIST 100 Index reached its first peak in April 2018. The depreciation of Turkish Lira in 2018 affected input prices of firms, and thus caused inflation. Therefore, Turkey followed tight monetary and fiscal policy in order to struggle with inflation. The positive reflection of this policies became apparent in the last quarter of 2019 and then Turkish economy started to recover. Afterwards, BIST 100 Index reached its second peak in February 2020 by rising strikingly between the period of October 2019 and February 2020. This period includes some exogenous factors besides the recovery of the Turkish economy such as increasing exports due to negative effects of Covid-19 pandemic in China and later in European economies. Thus, Turkish economy somehow became an alternative hub for exports. After this period, BIST 100 Index fell again sharply because of the deterioration of the global supply chain and appearance of the first Covid-19 case in Turkey. In sum, it can be appreciated that economic developments affect the activities and values of firms thereby these circumstances are reflected on equity market prices and returns.

Even though BIST 100 Index started to recover after the first shock of the first Covid-19 cases, the first jumping was approximately $7 \%{ }^{2}$ in March 24 , the Index continued to show worse performance compared to the period

\footnotetext{
${ }^{1}$ Note that some of the months cannot be seen on the Figure due to the fact that there are many months to consider.

2 The calculation is made by the authors by using related data from the Central Bank of Turkey.
} 
of March-April in 2018 and 2019. Lately, continuous compounding return of BIST 100 Index approximately $2.5 \%^{3}$. Starting from this, BIST 100 Index tended to decrease prominently during March 11-April 11 period corresponding to 2018 and 2019 whereas the index tends to increase during the same periods in the first three years. For this reason, it would make sense to compare the periods of the last three years to investigate the impact of Covid-19 pandemic.

In this context, the study aims to analyze the impact of Covid-19 pandemic on Turkish sectors by empirically comparing the stock returns and risks of the firms taken place in BIST 100. The periods of the comparison will cover the first month after outbreak of Covid-19, and the same period of time in 2018 and 2019.

The reason why such a study is important is that there are already some studies conducted within this relatively short period of time since the pandemic started. These studies aim to understand the immediate economic effects of the pandemic. The related literature in that regard will be mentioned in the next section. In this sense, it is important to understand the situation of Turkey -which is one of the top ten countries where pandemic has the most cases- compared to others about which the aforementioned studies have been conducted.

The rest of paper is structured as follows: Section 2 comprise of relevant literature. The methodology to be followed in this study is given in section 3. Afterward, the analyses specified in the methodology is included in section 4 . The next section 5 contains the findings. Finally, section 6 presents the conclusions.

\section{LITERATURE REVIEW}

Even though the outbreak of Covid-19 started just few months ago, literature about the impacts of it on different economies has increased since the virus revealed. In this regard, we will discuss about some of these literature examples below by grouping them according to their relevance and subject.

\subsection{Global Effects of Covid-19}

Firstly, there are some studies which take the issue at a global scale. Ozili and Arun (2020) discussed spillover effects of Covid-19 on global economy on the basis of social, health, monetary and fiscal policies implemented by sixteen countries. They came to the conclusion that restrictive social policies affected monetary and fiscal policies negatively because of lockdown and social distance.

By taking a different approach, Fernandes (2020) analyzed economic effects of Covid-19 outbreak on the world economy within different scenarios by applying basic statistical methods and graphical analyzes. According to the results, GDP growth of the twelve countries would take hit between $3 \%$ and $5 \%$ depending on country in the base scenario. In other scenarios, GDP might fall as much as $10 \%$. Besides that, each additional month for the outbreak would cost in range of $2-2.5 \%$ of global GDP.

Likewise, McKibbin and Fernando (2020) examined the impacts of different scenarios in terms of global macroeconomic outcome and financial markets by using DSGE model. The scenarios demonstrated that the pandemic is expected to reduce the world GDP by over $\$ 9$ trillion in 2020. In addition, the pandemic might cause consumptions and investments to drop. Hence, the drop in aggregate demand can cause a sharp decline in the stock market with original risk shocks.

\subsection{Effects of Covid-19 on Some Selected Countries}

As being two of the leading economies in the world today, the USA and China are of the more concern in relation to their vulnerability against Covid-19. In search of the answer of such a concern, Baker et al. (2020) analyzed the impact of the outbreak on the U.S. stock market by monitoring daily movements between 1985 and 2020 in order to compare with other disease outbreaks. As a result, they observed unprecedentedly more of the stock market volatility than previous outbreaks.

Onali (2020) searched the impact of Covid-19 outbreak on the US stock markets in mainly affected six countries. The results of their GARCH $(1,1)$ based model suggested that only the number of the cases and deaths in China affected returns of the US stock markets. Furthermore, VAR model suggested that number of deaths in France and Italy affected the stock market returns negatively.

\footnotetext{
${ }^{3}$ The calculation is made by the authors by using related data from the Central Bank of Turkey.
} 
Similarly, Yilmazkuday (2020) investigated Covid-19 pandemic effects on the S\&P 500 Index by using VAR model in between $31^{\text {st }}$ December 2019 and 12 ${ }^{\text {th }}$ March 2020. It was found out that one more death due to the virus resulted $0.02 \%$ of a cumulative reduction in the S\&P 500 Index after one-day; $0.06 \%$ of a cumulative reduction after one-week; and $0.08 \%$ of a cumulative reduction after one-month.

Besides the USA and China, the situation of some of the leading developed countries, especially the European ones, are also of the concern. In that regard, Zeren and Hizarc1 (2020) examined the impact of Covid-19 outbreak on stock markets within some selected countries by means of co-integration test which used both Covid-19 daily death and cases between the period of $23^{\text {th }}$ January 2020 and $13^{\text {th }}$ March 2020 . According to the findings, total cases had co-integration relation with Chinese, South Korean and Spanish stock markets, and had no co-integration relation with Italian, Franch and German stock markets.

In our work, projections about future growth rates in case of Turkey will be shared below.

\subsection{Relationship Between Stock Markets and Real Economy, and the Impact of Covid-19}

It is a known fact that there is a very close relationship between stock markets and real economy through various channels. In other words, stock markets have strong correlation with investment, production, output and demand. Since our aim in this paper is to analyze the effect of Covid-19 on different industries taken place at the stock market of Turkey, it is important to understand the relationship between stock markets and real economy in general, and the position of such a relationship under the impact of Covid-19.

Choi et al. (1999) analyzed the relationship between industrial production growth rates and lagged real stock returns for G-7 countries by way of using in-sample co-integration and error-correction models. The results of these empirical tests and the co-integration test showed a long-term equilibrium relationship between industrial production levels and stock prices meanwhile error-correction models showed a correlation between industrial production growth and lagged stock returns for all countries except Italy.

Yayla et al. (2017) investigated the relationship between stock markets and growth via ARDL model approach. As a result of the tests using BIST and industrial production index, a statistically significant co-integration relationship was found between the variables. The authors concluded that there was bidirectional causality between these variables in the short run, meanwhile there was a strong and positive causality from BIST index to industrial production in the long run.

Literature examples in that regard can be extended but the aim is just to show the existence of a general relationship between stock markets and real economy. On the other hand, such a relationship is open to the impact of different macroeconomic shocks such as the one caused by Covid-19. In search of such an impact, Ramelli and Wagner (2020) analyzed the impact of Covid-19 pandemic on different sectors by CAPM-adjusted returns and risks of stock markets in the US in their graphical investigation and OLS regressions which included three time periods, i.e. incubation, outbreak and fever period of the virus. They deduced that energy, consumer services and automobile sectors suffered whereas telecom industry did very well over the whole period. Besides that, food and staples retailing sectors were not affected significantly in the incubation and outbreak periods, but these sectors surged in fever period. On the contrary, health care industry became a winner in the first two periods, but this outperformance did not continue in the last period.

Yan et al. (2020) examined potential effects of Covid-19 pandemic on different sectors in different stock markets. They considered that the following sectors lost value quickly in the short-term, meaning between February 21-March 5: travel industry, technology sector, and entertainment industry. The findings showed that short selling of the stocks of these sectors was a likely way to make profit because of the panic sell-off in short-term period.

In conformity to the last two works mentioned above, our paper also attempts to understand the effects of Covid-19 pandemic on different sectors taken place in stock market of Turkey. Because, until now, impacts of Covid-19 pandemic related to Turkish economy have not been studied yet. There are only some general assessments without empirical analyses. For instance, Açıkgöz and Günay (2020) came to the conclusion that Turkish economy might be destroyed in the short term as the world but if Turkey can overcome the outbreak soon, this situation would bring sustainable growth in revenues of manufacturing, exports, and tourism sectors. Thus, our study aims to fill in the gap in this regard. 


\section{METHODOLOGY}

By employing a quantitative approach, this analysis used daily returns data of fifteen sectors of BIST 100 Index during March 11-April 11 periods of 2018, 2019 and 2020. In order to achieve the goal of this study, we used fifteen variables as shown on Table 1:

Table 1. Sectors Used as Variables, Their Symbols and Measures

\begin{tabular}{|c|c|c|}
\hline Variable & Symbol & Measure \\
\hline Finance \& Banking Sector & FBS & $\begin{array}{l}\text { Continuous compounding return derived from average daily } \\
\text { sector returns }\end{array}$ \\
\hline Multisectoral Holdings & $\mathrm{MH}$ & $\begin{array}{l}\text { Continuous compounding return derived from average daily } \\
\text { sector returns }\end{array}$ \\
\hline $\begin{array}{l}\text { Information, Technology \& } \\
\text { Telecommunication Sector }\end{array}$ & ITTS & $\begin{array}{l}\text { Continuous compounding return derived from average daily } \\
\text { sector returns }\end{array}$ \\
\hline Defense Industry & DI & $\begin{array}{l}\text { Continuous compounding return derived from average daily } \\
\text { industry returns }\end{array}$ \\
\hline Aviation Industry & $\mathrm{AI}$ & $\begin{array}{l}\text { Continuous compounding return derived from average daily } \\
\text { industry returns }\end{array}$ \\
\hline Construction Sector & CS & $\begin{array}{l}\text { Continuous compounding return derived from average daily } \\
\text { sector returns }\end{array}$ \\
\hline Energy \& Mining Sector & EMS & $\begin{array}{l}\text { Continuous compounding return derived from average daily } \\
\text { sector returns }\end{array}$ \\
\hline Petroleum Chemical Industry & PCI & $\begin{array}{l}\text { Continuous compounding return derived from average daily } \\
\text { industry returns }\end{array}$ \\
\hline Metallurgical \& Mechanical Industry & MMI & $\begin{array}{l}\text { Continuous compounding return derived from average daily } \\
\text { industry returns }\end{array}$ \\
\hline Motor Vehicle Industry & MVI & $\begin{array}{l}\text { Continuous compounding return derived from average daily } \\
\text { industry returns }\end{array}$ \\
\hline Durable Consumer Goods Sector & DCGS & $\begin{array}{l}\text { Continuous compounding return derived from average daily } \\
\text { sector returns }\end{array}$ \\
\hline Food, Wholesale \& Retail Sector & FWRS & $\begin{array}{l}\text { Continuous compounding return derived from average daily } \\
\text { sector returns }\end{array}$ \\
\hline Clothing \& Textile Sector & CTS & $\begin{array}{l}\text { Continuous compounding return derived from average daily } \\
\text { sector returns }\end{array}$ \\
\hline Health \& Pharmaceutical Industry & HPI & $\begin{array}{l}\text { Continuous compounding return derived from average daily } \\
\text { industry returns }\end{array}$ \\
\hline Other Sectors & $\mathrm{O}$ & $\begin{array}{l}\text { Continuous compounding return derived from average daily } \\
\text { other sectors returns }\end{array}$ \\
\hline
\end{tabular}

Source: BIST, Equity Market Bulletin Data, March 11-April 11 period in 2018,2019,2020.

The sector grouping seen on Table 1 was done by the authors. Since the number of firms in each sector changed during the given periods, this information is not included on Table 1. However, the firms that left and included in the BIST 100 Index at the first business day of April are considered. In order to conduct the empirical analysis, firstly, the returns of the firms in each sector were calculated over daily closing prices as shown by the following equation:

$$
r_{t}=\ln \left(P_{t}-P_{t-1}\right)
$$

And then, daily average returns of the sectors were calculated over daily firm return as shown by the following equation:

$$
\text { daily average return of the sector }=\frac{\text { aggregate return of firms in the sector }}{\text { number of firms in the sector }}
$$

Lastly, continuous compounding returns of the sectors for the above-mentioned periods were calculated by using daily average returns of the sectors. The related equation is as follows: 


$$
r_{a}(b)=\sum_{m=0}^{b-1} r_{a-m}
$$

$\mathrm{r}$ : continuous compounding return of the sector in the period of March 11-April 11

a: average return of the sector at April 11

$\mathrm{m}$ : average return of the sector at March 11

b: business days in the period of March 11-April 11

The basis of this study depends on return and risk analyzes of fifteen sectors in BIST 100 in the same periods of 2018, 2019 and 2020. Markowitz (1952) described risk as variance of security returns. Hence, the risk of the sectors was derived from variance of the continuous compounding return of each sector. Correspondingly, return and risk volatility of the sectors was compared in order to measure the effects of Covid-19 pandemic on fifteen sectors for three consequent years in that the response of each sector to the crisis is different, especially in the short run. Therefore, it was argued which sector was more consolidated in the early period of the outbreak. Besides, BIST 100 Index tends to decrease prominently during March 11-April 11 period corresponding to last three years whereas the index tends to increase during the same periods in the previous years. Accordingly, it would make sense to compare the periods of the last three years to investigate the impact of Covid-19 pandemic. Thus, the seasonal effect could be minimized.

In this context, descriptive statistics were analyzed in order to attain returns and risks of the sectors; sector correlations were investigated in order to examine variations of cross-sectoral interaction; and periodic risk and returns figures were included to observe distribution of returns and risks of the sectors, by using EViews 11 packaged software.

\section{ANALYSIS}

\subsection{Descriptive Statistics}

Table 2, 3, and 4 report descriptive statistics for the main variables used in this study for the aforementioned periods. Sum (\%), which is seen on each table, refers to continuous compounding return, and variance refers to risk of the sectors. Besides, standard deviation indicates how much the daily average sector returns deviate from the mean. In addition, skewness and kurtosis point to the direction of the deviation.

Table 2. Descriptive Statistics, March 11- April 11 period in 2018

\begin{tabular}{|c|c|c|c|c|c|c|c|c|c|}
\hline & Sum (\%) & $\begin{array}{c}\text { Variance } \\
(\%)\end{array}$ & $\begin{array}{c}\text { Mean } \\
(\%)\end{array}$ & $\begin{array}{c}\text { Median } \\
(\%)\end{array}$ & $\begin{array}{l}\text { Min. } \\
(\%)\end{array}$ & $\begin{array}{l}\text { Max. } \\
(\%)\end{array}$ & Std. Dev. & Skewness & Kurtosis \\
\hline FBS & -8.730 & 0.011 & -0.380 & -0.276 & -3.029 & 1.098 & 0.010376 & -0.515842 & 3.16131 \\
\hline MH & -1.256 & 0.018 & -0.055 & 0.163 & -4.034 & 1.902 & 0.013485 & -1.160286 & 4.77721 \\
\hline ITTS & -14.988 & 0.017 & -0.652 & -0.391 & -3.811 & 1.426 & 0.013193 & -0.734177 & 3.249023 \\
\hline DI & -13.053 & 0.020 & -0.568 & -0.519 & -4.190 & 1.734 & 0.014152 & -0.63325 & 3.327085 \\
\hline AI & 2.144 & 0.022 & 0.093 & 0.038 & -2.529 & 2.933 & 0.01476 & 0.128035 & 2.287924 \\
\hline CS & -11.394 & 0.018 & -0.495 & -0.251 & -3.558 & 1.945 & 0.013498 & -0.663964 & 3.061982 \\
\hline EMS & -7.959 & 0.033 & -0.346 & -0.146 & -3.471 & 3.705 & 0.01824 & 0.225763 & 2.477908 \\
\hline PCI & -4.201 & 0.019 & -0.183 & 0.159 & -3.162 & 2.073 & 0.013838 & -0.660305 & 2.937315 \\
\hline MMI & -4.835 & 0.014 & -0.210 & -0.337 & -2.041 & 1.848 & 0.011727 & 0.116722 & 1.801859 \\
\hline MVI & -9.074 & 0.013 & -0.395 & -0.490 & -3.002 & 2.914 & 0.011584 & 0.07906 & 5.656912 \\
\hline DCGS & -12.090 & 0.022 & -0.526 & 0.006 & -4.114 & 1.657 & 0.014754 & -1.045872 & 3.533816 \\
\hline FWRS & -12.162 & 0.009 & -0.529 & -0.532 & -2.317 & 1.513 & 0.009237 & 0.156287 & 2.499338 \\
\hline CTS & -5.765 & 0.023 & -0.251 & -0.505 & -2.701 & 2.335 & 0.0153 & 0.199929 & 1.827857 \\
\hline HPI & -5.620 & 0.028 & -0.244 & 0.299 & -3.167 & 2.280 & 0.016774 & -0.265419 & 2.006429 \\
\hline $\mathrm{O}$ & -10.872 & 0.049 & -0.473 & -0.652 & -4.743 & 4.675 & 0.022065 & 0.312219 & 3.305932 \\
\hline Average & -7.990 & 0.021 & -0.347 & -0.229 & -3.325 & 2.269 & 0.0141989 & -0.297407 & 3.060793 \\
\hline
\end{tabular}

As it is seen on Table 2, returns of the sectors variate in between -15\% (IITS), and -1.26\% (MH), except aviation industry for the period of March 11-April 2018. It is worth noting that only "aviation industry" (AI) provided profitability $(2.14 \%)$ during this period. The returns of "information, technology and telecommunication sector" (IITS), "defense industry" (DI), "food, wholesale and retail sector" (FWRS), "durable consumer goods 
sector" (DCGS) and "other sectors" $(\mathrm{O})$ draw attention by staying below the average return of the sectors ($7.99 \%$ ). On the other hand, risks of the sectors variate in between $0.009 \%$ (FWRS) and $0.049 \%(\mathrm{O})$. "Food, wholesale and retail sector" (FWRS), "finance and banking sector" (FBS), "motor vehicle industry" (MVI), "metallurgical and mechanical industry" (MMI) stand out as the least risky ones, whereas "other sectors" (O), "energy and mining sectors" (EMS), "hospital and pharmaceutical industry" (HPI) are the riskiest sectors. Moreover, skewness and kurtosis indicate that return flows are negative or positive by distributing the daily average sector returns to one tail.

Table 3 show returns and risks of the same sectors for the period of March 11-April 11 in 2019.

Table 3. Descriptive Statistics, March 11- April 11 in 2019

\begin{tabular}{|c|c|c|c|c|c|c|c|c|c|}
\hline & Sum (\%) & $\begin{array}{c}\text { Variance } \\
(\%)\end{array}$ & $\begin{array}{c}\text { Mean } \\
(\%)\end{array}$ & $\begin{array}{c}\text { Median } \\
(\%)\end{array}$ & $\begin{array}{c}\text { Min } \\
(\%)\end{array}$ & $\begin{array}{c}\text { Max } \\
(\%)\end{array}$ & Std. Dev. & Skewness & Kurtosis \\
\hline FBS & -6.541 & 0.048 & -0.273 & 0.263 & -6.133 & 3.047 & 0.021807 & -1.044947 & 4.159645 \\
\hline MH & -3.342 & 0.027 & -0.139 & 0.096 & -4.743 & 2.393 & 0.016315 & -0.89921 & 4.042544 \\
\hline ITTS & -10.616 & 0.063 & -0.442 & -0.008 & -7.733 & 3.943 & 0.025013 & -0.986554 & 4.557883 \\
\hline DI & -7.201 & 0.070 & -0.300 & 0.034 & -8.119 & 4.053 & 0.026436 & -0.785055 & 4.389603 \\
\hline AI & 1.268 & 0.054 & 0.053 & -0.029 & -5.205 & 3.969 & 0.023168 & -0.350291 & 2.48701 \\
\hline CS & -7.362 & 0.026 & -0.307 & -0.091 & -5.493 & 1.510 & 0.015971 & -1.799979 & 6.334402 \\
\hline EMS & -8.465 & 0.040 & -0.353 & -0.347 & -4.428 & 3.207 & 0.019926 & -0.274833 & 2.685094 \\
\hline PCI & -14.896 & 0.056 & -0.621 & -0.247 & -9.766 & 1.867 & 0.023716 & -2.599207 & 10.43934 \\
\hline MMI & -3.522 & 0.021 & -0.147 & -0.078 & -3.763 & 2.035 & 0.014579 & -0.944036 & 3.829015 \\
\hline MVI & -6.940 & 0.035 & -0.289 & -0.488 & -5.268 & 2.403 & 0.018653 & -0.797845 & 3.466491 \\
\hline DCGS & -5.623 & 0.062 & -0.234 & -0.308 & -6.000 & 5.802 & 0.024945 & -0.052228 & 3.791573 \\
\hline FWRS & -8.355 & 0.033 & -0.348 & -0.481 & -5.358 & 2.996 & 0.018213 & -0.439774 & 4.01758 \\
\hline CTS & -2.164 & 0.033 & -0.090 & 0.287 & -4.486 & 2.589 & 0.018145 & -0.662117 & 2.710102 \\
\hline HPI & 2.267 & 0.035 & 0.095 & 0.277 & -3.612 & 4.145 & 0.018615 & -0.015856 & 3.001791 \\
\hline $\mathrm{O}$ & -9.137 & 0.030 & -0.381 & -0.173 & -4.965 & 3.130 & 0.017225 & -0.43341 & 3.80106 \\
\hline Average & -6.042 & 0.042 & -0.252 & -0.086 & -5.671 & 0.031 & 0.020182 & -0.80569 & 4.247542 \\
\hline
\end{tabular}

As it is seen on Table 3, returns of the sectors variate in between $-15 \%$ (PCI) and -2.16\% (CTS), except "aviation industry" (AI), "health and pharmaceutical industry" (HPI) for the given period. Because, "aviation industry" $(1.27 \%)$, "health and pharmaceutical industry" (2.26\%) provided profitability. The returns of "petroleum chemical industry" (PCI), "information, technology and telecommunication sectors" (ITTS) and "other sectors" (O) draw attention by staying below the average return of the sectors (-6.02\%). On the other hand, risks variate in between 0.021\% (MMI) and 0.070\% (DI). "Metallurgical and mechanical industry" (MMI), "construction sector" (CS), "multisectoral holdings" (MH) stand out as the least risky sectors, whereas "defense industry" (DI), "information, technology and telecommunication sector" (ITTS), "durable consumer goods sector" (DCGS) are the riskiest sectors. Moreover, skewness and kurtosis indicate that return flows are negative or positive by distributing the daily average sector returns to one tail.

In addition, returns of the sectors are closer to the average return in 2019 compared to the same period of 2018. However, investment risk of the sectors has increased in 2019, except "other sectors" (O) due to exist and entry of the firms. Remarkable changes relevant to risk occurred in "finance and banking sector" (FBS), "information, technology and telecommunication sector" (ITTS), "defense industry" (DI), "durable consumer goods sector" (DCGS), "aviation industry" (AI), "food, wholesale and retail sector" (FWRS). Besides that, the interval between minimum and maximum sector returns widened in 2019. In other words, return volatility, i.e. risk of the sectors increased.

Table 4 shows return and risk situation of the same sectors for the same period (March 11-April 11) of 2020. 
Z. H. Orhan - N. Tirman 12/2 (2020) 2312-2326

Table 4. Descriptive Statistics, March 11- April 11 in 2020

\begin{tabular}{l|rrrrrrrrr}
\hline \multicolumn{1}{l}{} & \multicolumn{1}{c}{$\begin{array}{c}\text { Sum } \\
\text { (\%) }\end{array}$} & $\begin{array}{c}\text { Variance } \\
(\mathbf{\%})\end{array}$ & $\begin{array}{c}\text { Mean } \\
(\mathbf{\%})\end{array}$ & $\begin{array}{c}\text { Median } \\
\mathbf{( \% )}\end{array}$ & \multicolumn{1}{c}{$\begin{array}{c}\text { Min. } \\
(\mathbf{\%})\end{array}$} & $\begin{array}{c}\text { Max. } \\
(\mathbf{\%})\end{array}$ & Std. Dev. & Skewness & Kurtosis \\
\hline FBS & -3.169 & 0.144 & -0.138 & 0.068 & -10.162 & 6.760 & 0.037897 & -0.988027 & 4.244813 \\
MH & -2.070 & 0.136 & -0.090 & 0.336 & -9.185 & 6.547 & 0.036945 & -0.877591 & 4.059714 \\
ITTS & -1.746 & 0.220 & -0.076 & 0.031 & -12.996 & 7.588 & 0.046953 & -1.022812 & 4.077192 \\
DI & -3.138 & 0.173 & -0.136 & 0.717 & -10.510 & 9.356 & 0.041641 & -0.393559 & 3.77097 \\
AI & 6.673 & 0.364 & 0.290 & 1.002 & -11.034 & 8.466 & 0.060325 & -0.273329 & 1.801734 \\
CS & 0.169 & 0.148 & 0.007 & 0.185 & -8.542 & 6.185 & 0.038438 & -0.493687 & 3.234427 \\
EMS & -0.770 & 0.184 & -0.034 & 0.231 & -10.127 & 7.870 & 0.042872 & -0.585533 & 3.126689 \\
PCI & 2.377 & 0.140 & 0.103 & 0.677 & -9.597 & 7.063 & 0.037429 & -0.830843 & 3.913767 \\
MMI & -0.800 & 0.136 & -0.035 & 0.760 & -9.030 & 6.087 & 0.036811 & -1.055852 & 3.960275 \\
MVI & -12.291 & 0.177 & -0.534 & 0.654 & -10.767 & 6.292 & 0.042094 & -0.743757 & 3.305343 \\
DCGS & -8.753 & 0.195 & -0.381 & 0.103 & -10.891 & 7.518 & 0.044181 & -0.721899 & 3.414126 \\
FWRS & 4.800 & 0.178 & 0.209 & 0.763 & -10.496 & 6.645 & 0.042247 & -1.030185 & 3.967745 \\
CTS & -17.404 & 0.217 & -0.757 & 0.439 & -10.660 & 6.418 & 0.046564 & -0.613216 & 2.673095 \\
HPI & 9.206 & 0.465 & 0.400 & -0.586 & -10.452 & 13.156 & 0.068219 & 0.109561 & 2.133242 \\
O & 6.291 & 0.200 & 0.274 & 1.107 & -10.411 & 8.248 & 0.044715 & -0.784535 & 3.488845 \\
Average & -1.375 & 0.205 & -0.598 & 0.432 & -10.324 & 7.613 & 0.044488 & -0.687018 & 3.411465 \\
\hline
\end{tabular}

As it is seen on Table 4, negative returns of the sectors variate in between $-0.77 \%$ (EMS) and $-17 \%$ (CTS), whereas, positive returns of the sectors variate in between $0.17 \%$ (CS) and $9.21 \%$ (HPI). It is noteworthy that the returns of "aviation industry" (AI), "construction sector" (CS), "petroleum chemical industry" (PCI), "food, wholesale and retail industry" (FWRS), "health and pharmaceutical industry" (HPI) and "other sectors" (O) are positive. On the other hand, risks of the sectors variate in between $0.136 \%$ (MH and MMI) and $0.070 \%$ (HPI). Another important point is that health and "pharmaceutical industry" (HPI) have the highest return and risk ratios. "Multisectoral holdings" (MH), "metallurgical and mechanical industry" (MMI), "petroleum chemical industry" (PCI) and "construction sector" (CS) stand out as the least risky ones. Moreover, skewness and kurtosis indicate that return flows are negative or positive by distributing the daily average sector returns to one tail.

In addition to these, returns of the sectors in 2020 had the least return loss, whereas the period was exposed to the highest risk among 2018, 2019 and 2020. Also, the interval returns of the sectors which are in between minimum $-10.32 \%$ and maximum $7.63 \%$ are remarkable. This interval, i.e. risk, reached the highest level in 2020 among others. It is worth noting that "construction sector" (CS), "petroleum chemical industry" (PCI), "food, wholesale and retail sector" (FWRS) and "other sectors" (O) provided positive returns in 2020 whereas negative returns in 2018 and 2019. Lastly, "health and pharmaceutical industry" (HPI) in 2020 draw attention with its highest return among the overall sectors for the whole period of time.

\subsection{Correlations}

Table 5, 6, and 7 report sector correlations matrix in order to observe the relationship between the sectors for 2018, 2019, and 2020. Correlation coefficients move in between - 1 to 1 . If the correlation coefficient is closer to -1 , there is a strong inverse relationship between the sectors; if it is closer to 1, there is a strong linear relationship between the sectors; and if it is 0 , there is not a linear relationship between the sectors. 
Table 5. Sector Correlations, March 11- April 11 in 2018

\begin{tabular}{c|rrrrrrrrrrrrrrrr}
\hline \multicolumn{2}{c}{} & FBS & MH & ITTS & DI & AI & CS & EMS & PCI & MMI & MVI & DCGS & FWRS & CTS & HPI & O \\
\hline FBS & 1 & 0.68 & 0.53 & 0.42 & 0.60 & 0.73 & 0.61 & 0.45 & 0.72 & 0.37 & 0.42 & 0.64 & 0.46 & 0.48 & 0.18 \\
MH & 0.68 & 1 & 0.64 & 0.47 & 0.42 & 0.63 & 0.52 & 0.66 & 0.39 & 0.63 & 0.70 & 0.70 & 0.42 & 0.58 & 0.39 \\
ITTS & 0.53 & 0.64 & 1 & 0.55 & 0.58 & 0.57 & 0.51 & 0.64 & 0.50 & 0.71 & 0.68 & 0.61 & 0.75 & 0.49 & 0.48 \\
DI & 0.42 & 0.47 & 0.55 & 1 & 0.44 & 0.45 & 0.57 & 0.65 & 0.68 & 0.46 & 0.59 & 0.42 & 0.40 & 0.34 & 0.42 \\
AI & 0.60 & 0.42 & 0.58 & 0.44 & 1 & 0.35 & 0.45 & 0.45 & 0.54 & 0.38 & 0.44 & 0.43 & 0.61 & 0.47 & 0.26 \\
CS & 0.73 & 0.63 & 0.57 & 0.45 & 0.35 & 1 & 0.83 & 0.50 & 0.51 & 0.54 & 0.56 & 0.58 & 0.50 & 0.57 & 0.25 \\
EMS & 0.61 & 0.52 & 0.51 & 0.57 & 0.45 & 0.83 & 1 & 0.54 & 0.57 & 0.53 & 0.62 & 0.54 & 0.50 & 0.69 & 0.34 \\
PCI & 0.45 & 0.66 & 0.64 & 0.65 & 0.45 & 0.50 & 0.54 & 1 & 0.52 & 0.66 & 0.79 & 0.61 & 0.36 & 0.61 & 0.35 \\
MMI & 0.72 & 0.39 & 0.50 & 0.68 & 0.54 & 0.51 & 0.57 & 0.52 & 1 & 0.33 & 0.41 & 0.50 & 0.39 & 0.31 & 0.22 \\
MVI & 0.37 & 0.63 & 0.71 & 0.46 & 0.38 & 0.54 & 0.53 & 0.66 & 0.33 & 1 & 0.74 & 0.50 & 0.52 & 0.59 & 0.07 \\
DCGS & 0.42 & 0.70 & 0.68 & 0.59 & 0.44 & 0.56 & 0.62 & 0.79 & 0.41 & 0.74 & 1 & 0.60 & 0.39 & 0.70 & 0.50 \\
FWRS & 0.64 & 0.70 & 0.61 & 0.42 & 0.43 & 0.58 & 0.54 & 0.61 & 0.50 & 0.50 & 0.60 & 1 & 0.46 & 0.51 & 0.30 \\
CTS & 0.46 & 0.42 & 0.75 & 0.40 & 0.61 & 0.50 & 0.50 & 0.36 & 0.39 & 0.52 & 0.39 & 0.46 & 1 & 0.43 & 0.34 \\
HPI & 0.48 & 0.58 & 0.49 & 0.34 & 0.47 & 0.57 & 0.69 & 0.61 & 0.31 & 0.59 & 0.70 & 0.51 & 0.43 & 1 & 0.27 \\
O & 0.18 & 0.39 & 0.48 & 0.42 & 0.26 & 0.25 & 0.34 & 0.35 & 0.22 & 0.07 & 0.50 & 0.30 & 0.34 & 0.27 & 1 \\
\hline
\end{tabular}

According to the results of Table 5, there is a positive relationship between overall sectors. It means that none of the sectors is having an inverse relationship with one another. The strength of the correlation varies according to sector. "Multisectoral holdings" $(\mathrm{MH})$ have strong linear relationship regards to other sectors since they take part in many different sectors. Also, "finance and banking sector" (FBS) has strong correlation coefficient in comparison to other sectors. On the other hand, "other sectors" $(\mathrm{O})$ have weak relationship with rest of the sectors in general terms. "Energy and mining sectors" (EMS) and "petroleum chemical industry" (PCI) have the most consistent correlation coefficient, the reasons of which will be discussed in the upcoming section.

Table 6. Sector Correlations, March 11- April 11 in 2019

\begin{tabular}{c|rrrrrrrrrrrrrrrrr}
\hline \multicolumn{2}{c}{} & FBS & MH & ITTS & DI & AI & CS & EMS & PCI & MMI & MVI & DCGS & FWRS & CTS & HPI & O \\
\hline FBS & 1 & 0.83 & 0.81 & 0.76 & 0.60 & 0.86 & 0.80 & 0.42 & 0.85 & 0.81 & 0.64 & 0.75 & 0.57 & 0.67 & 0.75 \\
MH & 0.83 & 1 & 0.76 & 0.74 & 0.58 & 0.80 & 0.62 & 0.54 & 0.82 & 0.76 & 0.76 & 0.80 & 0.73 & 0.64 & 0.74 \\
ITTS & 0.81 & 0.76 & 1 & 0.60 & 0.52 & 0.80 & 0.58 & 0.38 & 0.71 & 0.64 & 0.60 & 0.80 & 0.63 & 0.59 & 0.66 \\
DI & 0.76 & 0.74 & 0.60 & 1 & 0.76 & 0.70 & 0.76 & 0.52 & 0.80 & 0.84 & 0.65 & 0.68 & 0.81 & 0.50 & 0.69 \\
AI & 0.60 & 0.58 & 0.52 & 0.76 & 1 & 0.70 & 0.82 & 0.64 & 0.78 & 0.73 & 0.68 & 0.75 & 0.69 & 0.45 & 0.62 \\
CS & 0.86 & 0.80 & 0.80 & 0.70 & 0.70 & 1 & 0.74 & 0.52 & 0.81 & 0.73 & 0.65 & 0.79 & 0.60 & 0.66 & 0.81 \\
EMS & 0.80 & 0.62 & 0.58 & 0.76 & 0.82 & 0.74 & 1 & 0.51 & 0.82 & 0.81 & 0.58 & 0.77 & 0.54 & 0.49 & 0.75 \\
PCI & 0.42 & 0.54 & 0.38 & 0.52 & 0.64 & 0.52 & 0.51 & 1 & 0.64 & 0.55 & 0.46 & 0.51 & 0.52 & 0.47 & 0.54 \\
MMI & 0.85 & 0.82 & 0.71 & 0.80 & 0.78 & 0.81 & 0.82 & 0.64 & 1 & 0.81 & 0.71 & 0.81 & 0.65 & 0.62 & 0.72 \\
MVI & 0.81 & 0.76 & 0.64 & 0.84 & 0.73 & 0.73 & 0.81 & 0.55 & 0.81 & 1 & 0.58 & 0.74 & 0.75 & 0.50 & 0.74 \\
DCGS & 0.64 & 0.76 & 0.60 & 0.65 & 0.68 & 0.65 & 0.58 & 0.46 & 0.71 & 0.58 & 1 & 0.71 & 0.70 & 0.52 & 0.71 \\
FWRS & 0.75 & 0.80 & 0.80 & 0.68 & 0.75 & 0.79 & 0.77 & 0.51 & 0.81 & 0.74 & 0.71 & 1 & 0.66 & 0.61 & 0.77 \\
CTS & 0.57 & 0.73 & 0.63 & 0.81 & 0.69 & 0.60 & 0.54 & 0.52 & 0.65 & 0.75 & 0.70 & 0.66 & 1 & 0.45 & 0.59 \\
HPI & 0.67 & 0.64 & 0.59 & 0.50 & 0.45 & 0.66 & 0.49 & 0.47 & 0.62 & 0.50 & 0.52 & 0.61 & 0.45 & 1 & 0.72 \\
O & 0.75 & 0.74 & 0.66 & 0.69 & 0.62 & 0.81 & 0.75 & 0.54 & 0.72 & 0.74 & 0.71 & 0.77 & 0.59 & 0.72 & 1 \\
\hline
\end{tabular}

According to the results of Table 6, there is a positive relationship between overall sectors. Generally, the correlation coefficients are greater than $50 \%$. Therefore, almost all sectors are in a stronger relationship with each other. It is noteworthy that the correlation of the "other sectors" $(\mathrm{O})$ with rest of the sectors became much stronger compared to 2018. 
Table 7. Sector Correlations, March 11- April 11 in 2020

\begin{tabular}{c|rrrrrrrrrrrrrrrr}
\hline \multicolumn{2}{c}{} & FBS & MH & ITTS & DI & AI & CS & EMS & PCI & MMI & MVI & DCGS & FWRS & CTS & HPI & O \\
\hline FBS & 1 & 0.92 & 0.80 & 0.86 & 0.82 & 0.89 & 0.91 & 0.89 & 0.94 & 0.90 & 0.91 & 0.68 & 0.83 & 0.29 & 0.93 \\
MH & 0.92 & 1 & 0.87 & 0.88 & 0.76 & 0.91 & 0.96 & 0.96 & 0.94 & 0.89 & 0.89 & 0.71 & 0.81 & 0.29 & 0.91 \\
ITTS & 0.80 & 0.87 & 1 & 0.80 & 0.66 & 0.74 & 0.89 & 0.87 & 0.78 & 0.81 & 0.81 & 0.76 & 0.80 & 0.52 & 0.82 \\
DI & 0.86 & 0.88 & 0.80 & 1 & 0.78 & 0.81 & 0.91 & 0.91 & 0.84 & 0.85 & 0.89 & 0.69 & 0.89 & 0.48 & 0.83 \\
AI & 0.82 & 0.76 & 0.66 & 0.78 & 1 & 0.80 & 0.81 & 0.78 & 0.82 & 0.88 & 0.87 & 0.38 & 0.90 & 0.34 & 0.85 \\
CS & 0.89 & 0.91 & 0.74 & 0.81 & 0.80 & 1 & 0.89 & 0.89 & 0.92 & 0.86 & 0.86 & 0.64 & 0.82 & 0.24 & 0.87 \\
EMS & 0.91 & 0.96 & 0.89 & 0.91 & 0.81 & 0.89 & 1 & 0.95 & 0.92 & 0.90 & 0.90 & 0.69 & 0.88 & 0.37 & 0.90 \\
PCI & 0.89 & 0.96 & 0.87 & 0.91 & 0.78 & 0.89 & 0.95 & 1 & 0.92 & 0.91 & 0.89 & 0.73 & 0.87 & 0.43 & 0.89 \\
MMI & 0.94 & 0.94 & 0.78 & 0.84 & 0.82 & 0.92 & 0.92 & 0.92 & 1 & 0.90 & 0.89 & 0.63 & 0.83 & 0.22 & 0.93 \\
MVI & 0.90 & 0.89 & 0.81 & 0.85 & 0.88 & 0.86 & 0.90 & 0.91 & 0.90 & 1 & 0.93 & 0.61 & 0.94 & 0.36 & 0.88 \\
DCGS & 0.91 & 0.89 & 0.81 & 0.89 & 0.87 & 0.86 & 0.90 & 0.89 & 0.89 & 0.93 & 1 & 0.55 & 0.94 & 0.30 & 0.88 \\
FWRS & 0.68 & 0.71 & 0.76 & 0.69 & 0.38 & 0.64 & 0.69 & 0.73 & 0.63 & 0.61 & 0.55 & 1 & 0.57 & 0.60 & 0.61 \\
CTS & 0.83 & 0.81 & 0.80 & 0.89 & 0.90 & 0.82 & 0.88 & 0.87 & 0.83 & 0.94 & 0.94 & 0.57 & 1 & 0.47 & 0.83 \\
HPI & 0.29 & 0.29 & 0.52 & 0.48 & 0.34 & 0.24 & 0.37 & 0.43 & 0.22 & 0.36 & 0.30 & 0.60 & 0.47 & 1 & 0.25 \\
O & 0.93 & 0.91 & 0.82 & 0.83 & 0.85 & 0.87 & 0.90 & 0.89 & 0.93 & 0.88 & 0.88 & 0.61 & 0.83 & 0.25 & 1 \\
\hline
\end{tabular}

According to the results of Table 7, there is a positive relationship between all sectors. The correlation coefficients of the sectors are mostly 80-90\%, except "health and pharmaceutical industry" (HPI), "food, wholesale and retail sector" (FWRS). In other words, overall sectors have strong linear relationship with each other, except "health and pharmaceutical industry" (HPI), "food, wholesale and retail sector" (FWRS). Also, "health and pharmaceutical industry" (HPI) has weak correlation with rest of the sectors. Besides, "food, wholesale and retail sector" (FWRS) has weak correlation coefficients compared to the rest of the sectors.

Even though sector correlation coefficients varied in 2018, they started to increase in the same period of 2019, and they reached the strongest relationship with each other in 2020.

\subsection{Risk and Return Distributions}

Figure 2, 3, and 4 show periodic risk and return distribution of the sectors in 2018, 2019, and 2020. Variance implies risk ratio of the sectors and shown on $\mathrm{x}$-axis whereas return is shown on $\mathrm{y}$-axis.

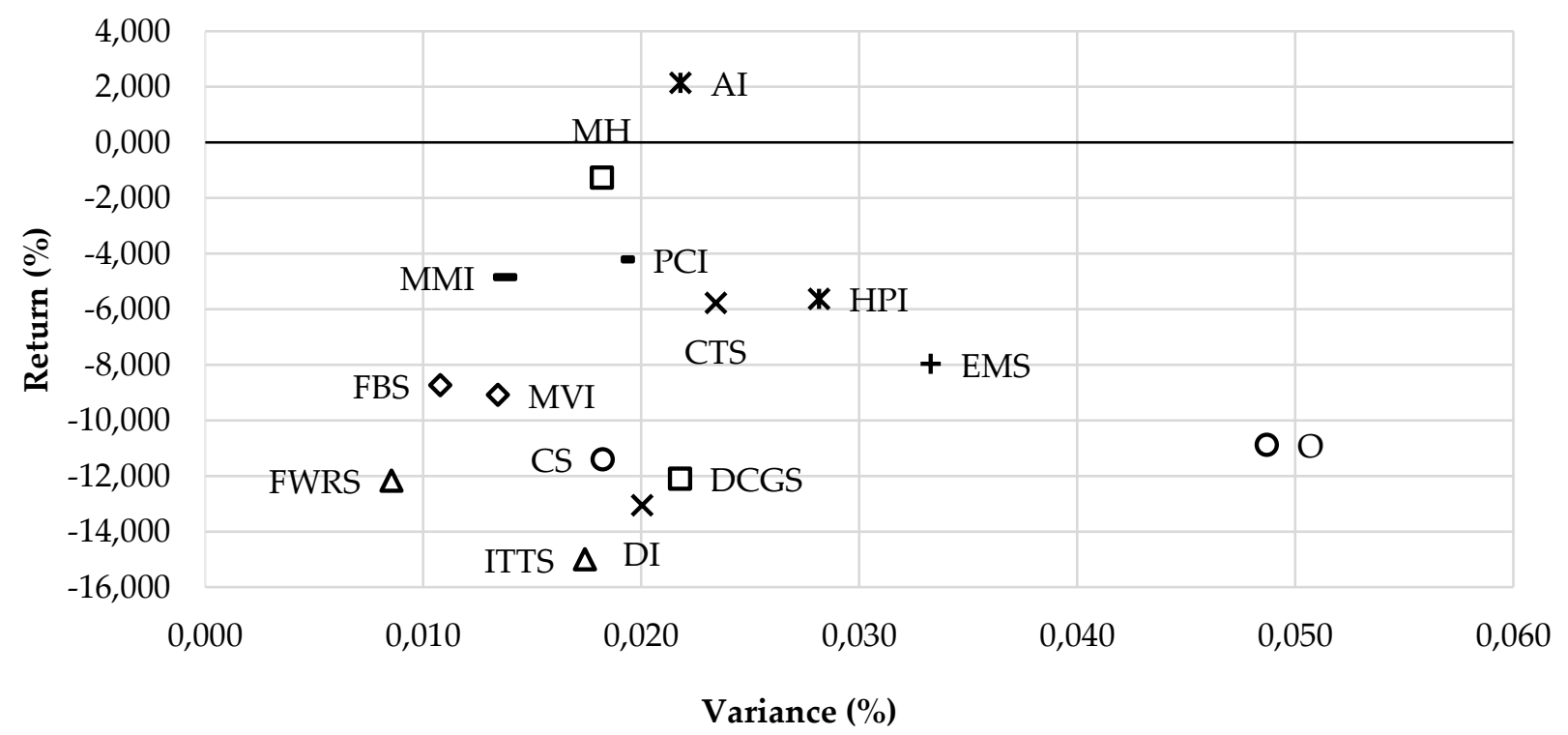

Figure 2. Periodic Risk and Return, March 11-April 11 in 2018

Figure 2 shows that risk-return pairs scatter vertically within negative returns and risk interval of $0.01 \%$ to $0.03 \%$ in general. As an exception, "aviation industry" (AI) has an average risk ratio and a positive return. As another outlier, "energy and mining sector" (EMS) has both quite high risk and average return ratio. On the 
other hand, "other sectors" $(\mathrm{O})$ has high risk but low return. Besides, "food, wholesale and retail sector" (FWRS) has also low return but low risk as well.

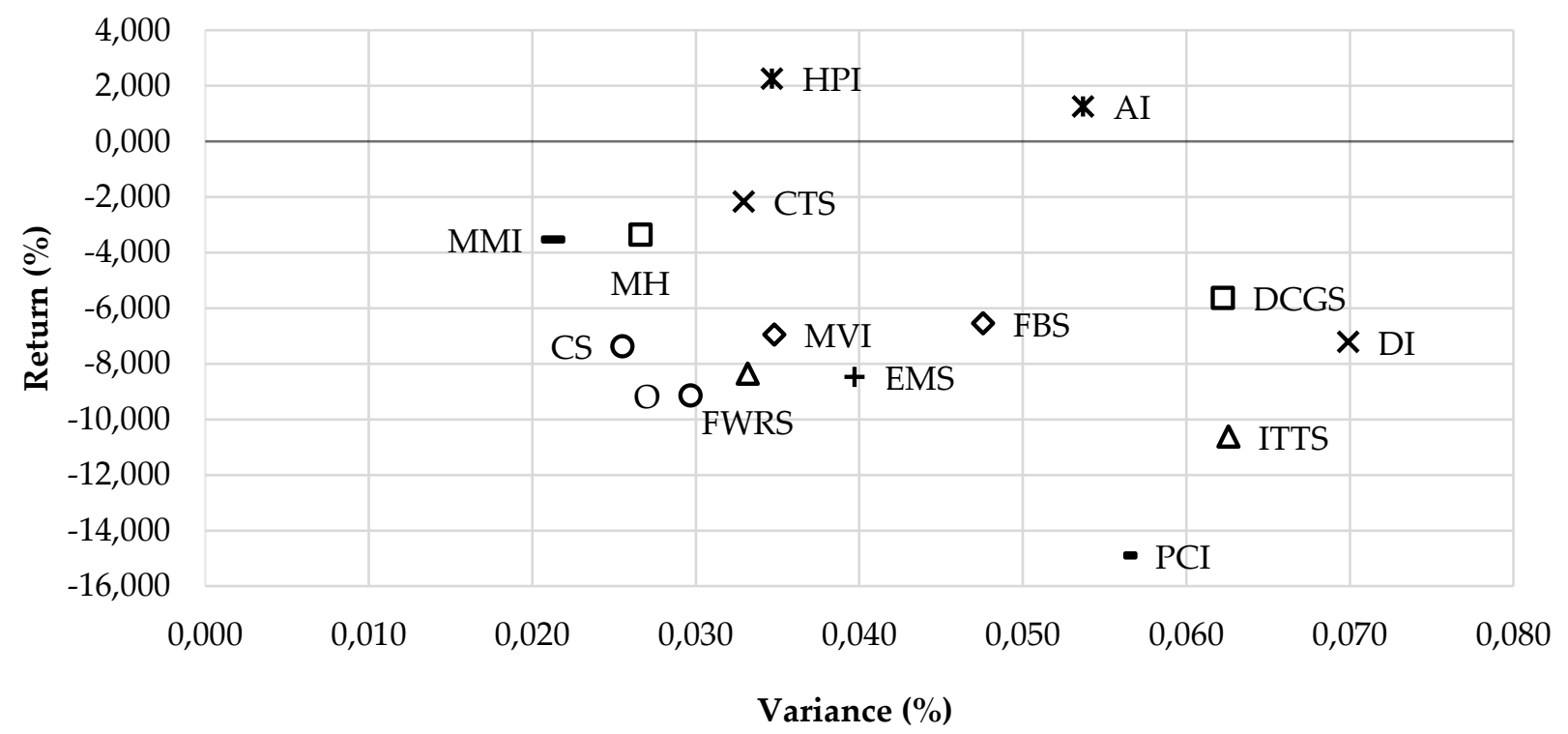

Figure 3. Periodic Risk and Return, March 11-April 11 in 2019

Figure 3 shows that risk-return pairs scatter horizontally within negative returns and risk interval of $0.02 \%$ to $0.07 \%$, except "aviation industry" (AI) and "health and pharmaceutical industry" (HPI). "Aviation industry" (AI) has quite high-risk ratio but positive return. In addition, "health and pharmaceutical industry" (HPI) has moderate risk with the highest positive return. On the other hand, "defense industry" (DI) has the highest risk with average returns. Also, "Petroleum chemical industry" (PCI) has quite high-risk ratio with the lowest return. Lastly, "metallurgical and mechanical industry" (MMI) has the lowest risk but also low return as well.

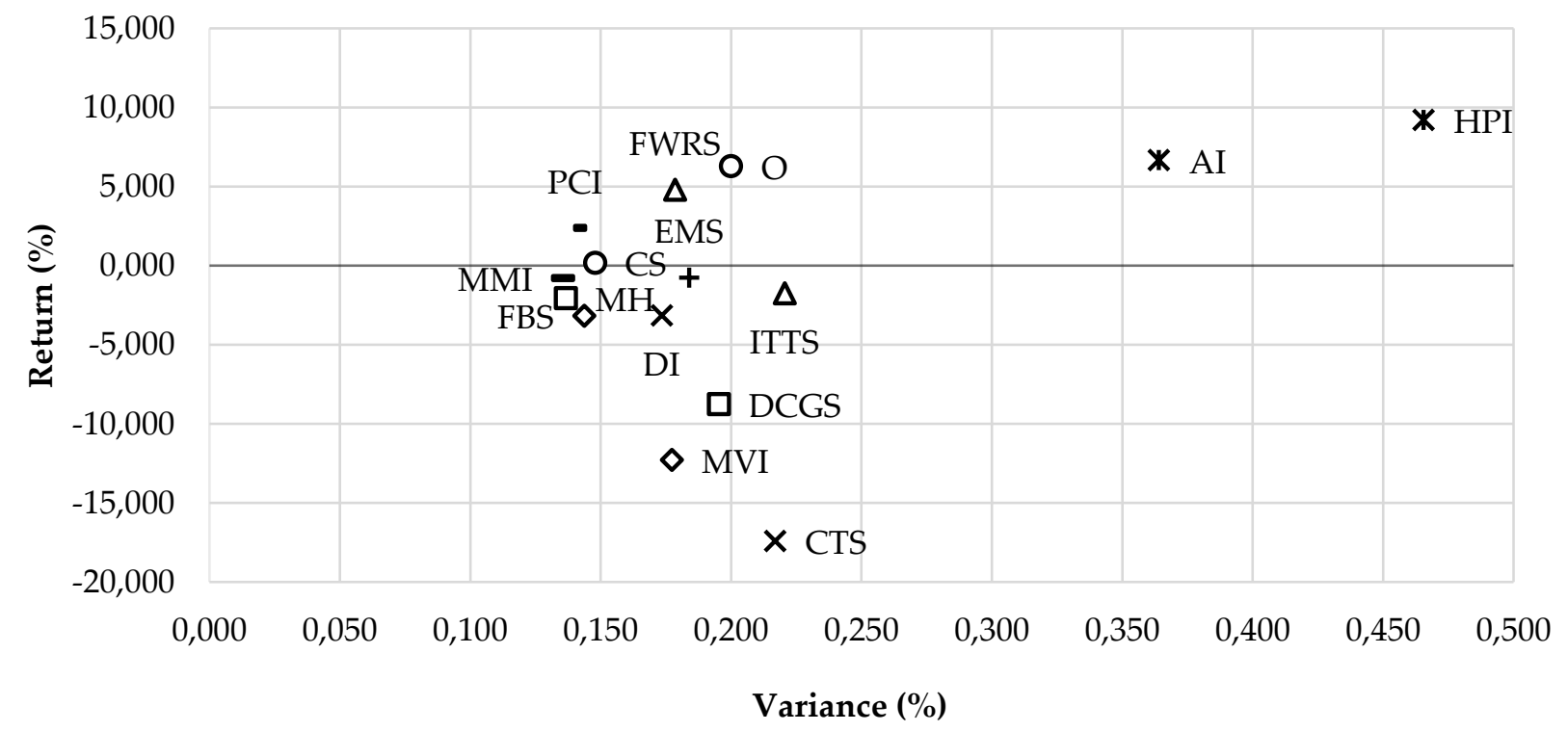

Figure 4. Periodic Risk and Return, March 11-April 11 in 2020

Figure 4 shows that risk-return pairs scatter very close to each other in risk range of $0.10 \%$ to $0.20 \%$ and return range of $-5 \%$ to $5 \%$ for most of the sectors. "Health and pharmaceutical sector" (HPI) has not only the highest risk but also the highest return as the most outstanding sector among others. Correspondingly, "aviation industry" (AI) has both relatively high risk and high return. Besides that, "other sectors" (O) has an average risk ratio, and a positive return. On the other hand, "clothing and textile sector" (CTS) has an average risk with the least return. Last but not the least, both "motor vehicle industry" (MVI) and "durable consumer goods sector" (DCGS) have average risk but quite low returns. 
If Figure 2, 3, and 4 are comparatively analyzed, it can be noticed that the sectors taken place in this study scatter around the average the most in 2018 whereas risk-return pairs come closest to each other in 2020 . There are some exceptions though; "health and pharmaceutical industry" (HPI) stand out as outliers with their high combinations of risk and return in 2020.

A sector which seems not to change its place in terms of the risk-return scheme is "clothing and textile sector" (CTS) since its situation did not change so much in between 2018 and 2019, and it just moved a bit down in 2020 , meaning that its return decreased a bit compared to the previous two years.

In terms of horizontal movement, "defense industry" (DI) keeps its place in 2018 and 2020 but its variance, meaning risk, increased much in 2019.

\section{DISCUSSION}

BIST 100 Index lost value for the periods of March 11-April 11 in the 2018, 2019 and 2020. The possible reasons of this situation are depreciation of Turkish Lira in 2018, negative growth in the first three quarters of 2019, and Covid-19 pandemic in 2020. Hence, comparison of these successive periods is significant in order to compare the economic problems pertaining to dynamics of Turkish economy, and economic problems caused solely by Covid-19 pandemic.

The loss in returns of BIST 100 Index has been decreasing gradually from $-7.72 \%$ to $-2.74 \%$, and finally to $2.46 \%$ respectively in 2018,2019 , and 2020 . However, the index is becoming riskier with variances of $0.007 \%$, $0.011 \%, 0.208 \%$ respectively in 2018,2019 , and 2020 . Relatively small changes in the rate of returns can be explained by idiosyncratic dynamics of Turkish economy and global economic fluctuations in the given periods. On the other hand, the excessive increase in risk -especially in the last two periods- can be explained by the impacts of Covid-19 pandemic. In spite of the extreme risk during the first periods of Covid-19 pandemic, increase in the returns of the "health and pharmaceutical industry" (9.21\%), "aviation industry" $(6.68 \%)$, "other sectors" (6.30\%), "food, wholesale and retail sector" $(4.80 \%)$, and "petroleum chemical industry $(2.38 \%)^{\prime \prime}$ might have caused the index not to decrease its average return too much. Thus, they counterbalanced the negative turn in the index during the last period. It should be noted however that, "other sectors" $(\mathrm{O})$, "food, wholesale and retail sector" (FWRS) and "petroleum chemical industry" (PCI) had negative returns in the previous periods.

"Aviation industry" (AI) had positive return in the entire periods. It is worth noting that AI sustained positive return (6.67\%) in the period of Covid-19 pandemic as well. In this sense, Yan et al. (2020) examined potential effects of Covid-19 pandemic on different sectors in different stock markets. They came to conclusion that travel industry is one of the sectors losing value quickly in the short-term. Accordingly, it is useful to examine firms of Turkish aviation industry on Table 8.

Table 8. Returns and Variances of the Firms of Aviation Industry, Marc11-April11 in 2020

\begin{tabular}{llcc}
\hline Type of Industry & Firm & Return (\%) & Variance (\%) \\
\hline Ground Services & CELEBI & 5.790235079 & 0.532131793 \\
Airline & PEGASUS & 20.08233622 & 0.788185588 \\
Airport Operations & TAV AIRPORTS & 2.537367235 & 0.245035005 \\
Airline & TURKISH AIRLINES & -1.71981983 & 0.242941295 \\
\hline
\end{tabular}

Source: BIST, Equity Market Bulletin Data, March 11- April 11 period in 2020.

As it is seen on Table 8, returns of the firms in AI were not negatively affected by Covid-19 pandemic, except Turkish Airlines since it is the only firm which had negative return during the aforementioned period. On the other hand, the high return rate (20\%) of Pegasus is remarkable, especially when the latest tragic incidences are taken into account. Thus, the situation of Pegasus requires further elaboration. Nevertheless, the firms have rather high risk, including Pegasus as well.

The sub-sectors included by "other sectors" $(\mathrm{O})$ vary from period to period. For instance, the firms of entertainment and media sectors were included in the BIST 100 Index for the given period in 2018 and 2019, but not in 2020. Therefore, analysis of the $\mathrm{O}$ gives different results for each period. For this reason, it is not possible to make an accurate analysis about the $\mathrm{O}$. 
Covid-19 pandemic affected raw material prices in many sectors or industries. As one of them, petroleum prices decreased sharply due to decreasing aggregate demand and production relevant to petroleum prices in the world. "Petroleum chemical industry" (PCI) had positive return $(2.38 \%)$ because of decreasing input cost in the first period of Covid-19 pandemic, whereas PCI had negative return in the previous period. Besides that, PCI had the second lowest risk ratio (0.140) in the Covid-19 pandemic period. This situation expresses that Turkish petroleum chemical industry production was not negatively affected from Covid-19 pandemic as some of the other sectors. Correspondingly, PCI is one of the locomotive industries of Turkey as in many emerging countries. Correspondingly, as it can be seen on Table 5, 6, and 7, PCI has consistent relationship with overall sectors throughout the entire period.

Even though sector correlation coefficients varied normally, meaning not so strongly in 2018, the correlations started to increase in the same period of 2019, and they reached their highest levels during the first period of Covid-19 pandemic in 2020, except "health and pharmaceutical industry" (HPI), and "food, wholesale and retail sector" (FWRS), as it can be seen on Table 5, 6, and 7. In other words, the sectors were affected as a whole from economic contraction in 2019, and they were affected much more by Covid-19 pandemic, except the aforementioned sectors. It means that the other sectors except FWRS and HPI reacted Covid-19 more and varied together. Thus, correlation coefficients among them increased. On the other hand, the exceptional situation of FWRS and HPI depends on the fact that they are the primary needs of people.

"Health and pharmaceutical industry" (HPI) had negative return $(-5.62 \%)$ and relatively low risk $(0.028)$ in 2018 , but it had positive return (2.27\%) in the same period of 2019. However, HPI had not only the highest return $(9.21 \%)$ but also the highest risk (0.47) as the most outstanding sector among others in early periods of Covid-19 pandemic. While the importance of HPI had increased, uncertainties also increased the risk of the sector. On the other hand, Covid-19 virus is related to human health, before anything else. Therefore, HPI had weak relationship with rest of the fourteen sectors in Covid-19 pandemic period since HPI acts differently than the remaining sectors due to the strong relationship between HPI and Covid-19 pandemic.

Furthermore, "food, wholesale and retail sector" (FWRS) kept consistent correlation coefficient for the same periods in 2018, 2019 and 2020. Although the remaining thirteen sectors (besides HPI and FWRS) had strong relationship with each other in the previous periods, and correlation coefficient of FWRS stayed almost unchanged in the Covid-19 pandemic period because of the necessity of them for human life. In addition, FWRS was one of the most profitable (4.80\%) sectors in Covid-19 pandemic period, whereas FWRS had lowest return in the same period of $2018(-12.16 \%)$ and 2019 (-8.36). It means that people attached more importance to the consumption of necessary goods than ever before in order to sustain their lives in an environment of uncertainty resulting from Covid-19 pandemic. Besides that, FWRS had also high-risk ratio profile like many sectors in Covid-19 pandemic period compared to the previous periods.

Moreover, "finance and banking sectors" (FBS) and "multisectoral holdings" (MH) had strong correlation coefficient -except "health and pharmaceutical industry" (HPI) and "food, wholesale and retail sector" (FWRS)- during the given periods of 2019 and 2020 but also rather good relationship with each other in the same period of 2018. As it is known, FBS provides finance to the sectors, and, MH contains many sectors in itself. Hence, it is usual for these sectors to act concomitantly. In this sense, FBS and MH allocate the risk according to the sectors. Correspondingly, $\mathrm{MH}$ had the lowest risk ratio $(0.136 \%)$, and FBS $(0.140 \%)$ had the third lowest risk ratio in the Covid-19 pandemic period. Nevertheless, these sectors -FBS $(-3.20 \%)$ and MH (2.07)- had negative return ratios due to adverse effects of Covid-19 pandemic in the world and in Turkey.

In sum, the most profitable sectors during the first period of Covid-19 in Turkey were as follows: HPI with 9.21\% return, AI with $6.67 \%$ return, and O with $6.39 \%$ return. On the other hand, the sectors which had the highest loss in their returns during this period were the followings: CTS with $-17.40 \%$ return, MVI with $12.30 \%$ return, and DCGS with $-8.75 \%$ return. In terms of riskiness, the ones which had the highest risk during the first period of the pandemic were respectively HPS, AI, and ITTS. On the other hand, the least risky sectors became MH, MMI, PCI, and FBS. The low riskiness can be attributed to the risk spreading factor of the first sector, and relatively stability of the second one. 


\section{CONCLUSION}

Covid-19, which appeared in China in December 2019, became a pandemic by spreading all over the world. The studies which have been conducted so far about the subject exhibited that the pandemic disrupted global supply chain, production, trading and markets, so overall dynamics of economics.

In this study, we examined the impact of Covid-19 pandemic on fifteen Turkish sectors which are taken place in BIST 100 Index by analyzing return and risk of these sectors during the period of March 11-April 11 in 2020 in comparison to the same periods of 2018 and 2019. In doing this, empirical analyses including descriptive statistics, sector correlations and risk-return schemes were used.

In result of the analyses, it was found that risk of the all sectors had increased extremely during the first period of the Covid-19 pandemic (averagely 0.205\%) compared to the same period of 2019 (averagely $0.042 \%$ ) and compared to same period of 2018 (averagely $0.021 \%$ ). However, the average loss in returns of the sectors had decreased gradually from $-7.99 \%$ to $-6.04 \%$, and finally to $-1.38 \%$ respectively in the given periods of 2018 , 2019, and 2020.

In sum, the most profitable sector during the first period of Covid-19 in Turkey was "health and pharmaceutical industry" with $9.21 \%$ return whereas the sector which had the highest loss in its return during this period was "clothing and textile sector" with $-17.40 \%$ return. That can be related to the necessity of the first one while the relatively unnecessity of the second one. Also, it should be kept in mind that shopping malls in which stores of clothing and textile sector taken place were closed down throughout the period. In terms of riskiness, the sector which had the highest risk during the first period of the pandemic was also "health and pharmaceutical sector" which may prove the close correlation between risk and return in finance literature. On the other hand, the least risky sectors were "multi-sectoral holdings" and "metallurgical and mechanical industry."

These results can guide us regarding especially which sectors can be vulnerable for the possible future crises, and which sectors may especially need financial support by economic-political measures.

\section{REFERENCES}

Açıkgöz, Ö., \& Günay, A. (2020). The early impact of the Covid-19 pandemic on the global and Turkish economy. TURKISH JOURNAL OF MEDICAL SCIENCES, 50(3). https://doi.org/10.3906/sag-2004-6

Baker, S. R., Bloom, N., Davis, S. J., Kost, K., Sammon, M., \& Viratyosin, T. (2020). The Unprecedented Stock Market Reaction to COVID-19. Retrieved from https://www.policyuncertainty.com/media/StockMarkets_COVID.pdf

BIST (Borsa Istanbul). (April 18, 2020). Equity Market Bulletin Data. Retrieved from https://www.borsaistanbul.com/en/data/data/equity-market-data

CBRT (Central Bank of Republic of Turkey). (April 18, 2020). EVDS I Borsa Istanbul Trading Volume, Price and Return Indices BIST 100 All Shares Index, According to Closing Price. Retrieved from https://evds2.tcmb.gov.tr/index.php?/evds/serieMarket/\#collapse_1

Choi, J. J., Hauser, S., \& Kopecky, K. J. (1999). Does the stock market predict real activity? Time series evidence from the G-7 countries. Journal of Banking and Finance, 23(12), 1771-1792. https://doi.org/10.1016/S03784266(99)00020-5

Fernandes, N. (2020). Economic Effects of Coronavirus Outbreak (COVID-19) on the World Economy. SSRN Electronic Journal. https://doi.org/10.2139/ssrn.3557504

IMF (International Monetary Fund). (2020). World Economic Outlook, April 2020. Retrieved from https://www.imf.org/en/Publications/WEO/Issues/2020/04/14/weo-april-2020

Markowitz, H. (1952). PORTFOLIO SELECTION. The Journal of Finance, 7(1), 77-91. https://doi.org/10.1111/j.1540-6261.1952.tb01525.x

McKibbin, W. J., \& Fernando, R. (2020). The Global Macroeconomic Impacts of COVID-19: Seven Scenarios. SSRN Electronic Journal. https://doi.org/10.2139/ssrn.3547729 
Z. H. Orhan - N. Tirman 12/2 (2020) 2312-2326

Onali, E. (2020). COVID-19 and Stock Market Volatility. SSRN Electronic Journal. https://doi.org/10.2139/ssrn.3571453

Ozili, P. K., \& Arun, T. (2020). Spillover of COVID-19: Impact on the Global Economy. SSRN Electronic Journal. https://doi.org/10.2139/ssrn.3562570

Ramelli, S., \& Wagner, A. F. (2020). Feverish Stock Price Reactions to the Novel Coronavirus. SSRN Electronic Journal. https://doi.org/10.2139/ssrn.3550274

T.R. Ministry of Health. (April 11, 2020). T.C Sağlık Bakanlığı Korona Tablosu. Retrieved from https://covid19.saglik.gov.tr/\#

WHO (World Health Organization). (April 11, 2020). Coronavirus Disease 2019 (COVID-19): Situation Report-82. Geneva. Retrieved from https://www.who.int/docs/default-source/coronaviruse/situationreports/20200411-sitrep-82-covid-19.pdf?sfvrsn=74a5d15_2

Yan, B., Logan, S., Tu, A., \& Zhang, T. (2020). Analysis of the Effect of COVID-19 on the Stock Market and Potential Investing Strategies. SSRN Electronic Journal. Retrieved from https://ssrn.com/abstract $=3563380$

Yayla, N., Ceylan, R., \& Çeviş, İ. (2017). TÜRKIYYE’DE HİSSE SENETLERİ PIYASASI İLE EKONOMIKK BÜYÜME İLIŞKİSINE ARDL YAKLAŞIMI. Social Sciences, 12(4), 185-198. Retrieved from http://dergipark.org.tr/en/pub/nwsasocial/issue/31527/339055

Yilmazkuday, H. (2020). COVID-19 Effects on the S\&P 500 Index. SSRN Electronic Journal. https://doi.org/10.2139/ssrn.3555433

Zeren, F., \& Hizarc1, A. (2020). THE IMPACT OF COVID-19 CORONAVIRUS ON STOCK MARKETS: EVIDENCE FROM SELECTED COUNTRIES. Muhasebe ve Finans Incelemeleri Dergisi, 3(1), 78-84. https://doi.org/10.32951/mufider.706159 